Davenport) paid tribute to Sir William's distinguished work in algebraic and differential geometry. Prof. Davenport briefly reviewed the Society's affairs, and announced that a loan granted by the Nuffield Foundation had enabled the Society to begin reprinting those of its publications which are out of print. He also announced that the Oxford University Press had agreed to publish the Collected Papers of G. H. Hardy, with the assistance of an editorial board appointed by the Society. Prof. H. Heilbronn (University of Bristol) was elected president for the ensuing session. The retiring president delivered his presidential address on "Some Recent Progress in the Analytic Theory of Numbers".

\section{Model Marine Engines}

Liverpool Public Museums have recently placed on exhibition a series of working models of steam reciprocating marine engines. They cover the period 1837-1937 and start with the side-lever paddle engine of 1837. Then comes a set of oscillating cylinder paddle engines of the 1840's. Also in the paddle engines section is a set of diagonal compound machinery of about 1890 . Screw propulsion came into general use during the 1840 's and ' 50 's, and the earliest model is of the horizontal return connecting. rod type. All the remaining screw engines are inverted direct-acting. The models are displayed working, and the side-lever and oscillating cylinder engines run at ten and twelve revolutions a minute, which is their correct working speed. The other models run at forty revolutions a minute, which is well below the average speed of their real prototypes. Running at this low speed is necessary, however, to preserve the bearings of the models, for they have been acquired for posterity as well as the present generation. The models are fully described in a paper by Mr. E. W. Paget-Tomlinson in the October issue of the Museums Journal.

\section{Replicas of Workshops}

THE Museums Journal of September includes an account by Mr. Keith Dunham of the workshops which have been reconstructed in the Museum of Science and Industry at Birmingham. The city has always had a reputation for a multiplicity of trades, all of which have grown from the skill in iron-working possessed by the inhabitants since early times. The building erected in the mid-nineteenth century in which this Museum is now housed was formerly the premises of a firm of silversmiths and electroplaters, and thus gives an excellent background for reconstruction of early workshops. The trades chosen were those of the brass-turner, the action filer (gunmaker), the nailer, the jeweller and the cooper. The workshops of a silversmith and brass-founder were already in existence. Details of the display are given in the paper quoted.

\section{Phycology in Britain}

THe recent issue of the British Phycological Bulletin (No. 7, July 1959) contains the presidential address, "Buoyancy in Relation to the Ecology of the Freshwater Phytoplankton", presented to the Society by Dr. J. W. G. Lund, together with abstracts of the other papers read at the London meeting in January 1959. There are also the first part of a list of the chromosome numbers in the Chlorophyta, notes on the algal herbaria of Hudson and Lightfoot, a list of marine algae collected in the course of field excur- sions organized during the Third International Seaweed Symposium held in Galway in July 1958, reviews of recent phycological literature and a number. of shorter articles.

\section{Prize for Man-powered Aircraft Flight}

THE Royal Aeronautical Society announces that a

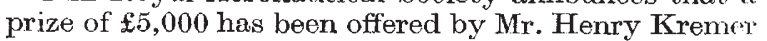
for the first successful flight of a man-powered air. craft, designed, built and flown within the British Commonwealth under conditions to be laid down by the Royal Aeronautical Society. The Royal Aero Club is to be invited to act as official observers. The prize is offered personally by Mr. Kremer and not by any of the companies with which he is associated. Mr. Kremer has been on the production side of industry all his life, and before the War pioneered the resin-bonded composition board industry. After the War he began to take an interest in plastics, and in 1950 he formed Microcell, Ltd., which has been extended to include an aircraft engineering division and an electronics division, as well as the plastics division. Since 1950 two other companies have expanded under his chairmanship, narnely, Glass Yarns and Deeside Fabrics, Ltd., producing glass fibre, and Artrite Resins, Ltd. Microcell, Ltd., has since merged with BTR Industries.

\section{Postdoctoral Awards : U.S. National Science Foun- dation}

Postdoctorat fellowships are offered by the U.S. National Science Foundation to citizens of the United States with special aptitude for advanced training and who hold the doctoral degree or have the equivalent in training or experience. Fellowships will be awarded in the mathematical, physical, medical, biological, engineering and other science fields, including anthropology, psychology (other than clinical), geography, certain interdisciplinary fields and selected social science fields. A grant of 4,500 dollars a year will be awarded to successful applicants under the postdoctoral fellowship programme. Dependency allowances will be made to married Fellows. Fellows may engage in study and/or research at appropriate non-profit American or non-profit foreign institutions. A limited allowance to aid in defraying a Fellow's cost of travel will also be available. Further information can be obtained from the Fellowship Office, National Academy of Sciences-National Research Council, 2101 Constitution Avenue, N.W. Washington 25, D.C. All applications must be made by December 22.

\section{"Animal Clocks"}

ReFerring to the report of his paper at the York meeting of the British Association in the symposium on "Animal Clocks", published in Nature of Septem. ber 12, p. 763 , Dr. Malcolm B. Wilkins states that the last two sentences should read as follows: "The period of the rhythm is slightly sensitive to temperature. Ball and Dyke have shown that the growth-rate rhythm in Avena coleoptiles is inhibited in nitrogen, and Bünning has shown that the period of the rhythm of leaf movement of Phaseolus multiflorus is increased by the mitotic poisons colchicine and phenylurethane."

\section{University News :}

Leeds

The following grants are announced: $£ 4,310$ for the period of one year from the National Coal Board. 